\title{
PERBEDAAN PENGETAHUAN DAN KETRAMPILAN PESERTA TERHADAP PENYUSUNAN STRUKTUR ORGANISASI SEBELUM DAN SESUDAH PELATIHAN
}

\author{
Sarwo Edy Handoyo ${ }^{1}$, Herlin Tundjung Setijaningsih ${ }^{2}$, dan Sukis Warningsih ${ }^{3}$ \\ ${ }^{1}$ Dosen Jurusan Manajemen, Universitas Tarumanagara Jakarta \\ Email:sarwoh@fe.untar.ac.id \\ 2 Dosen Jurusan Akuntansi, Universitas Tarumanagara Jakarta \\ Email: herlins@fe.untar.ac.id \\ ${ }^{3}$ Mahasiswa Jurusan Manajemen, Universitas Tarumanagara Jakarta
}

\begin{abstract}
Religious organizations such as the youth organization of the mosque have a strategic role in the prosperity of the mosque. The prosperous mosque is marked by the lively worship activities of its worshipers. In Al Barokah Mosque, Cobodas Sub-District, Tangerang City, the organization of mosque teenagers is not running well and regularly. Based on observations and interviews with administrators of the Mosque Prosperity Board, the root of the problem is the lack of knowledge to compile an effective and efficient youth organization structure of the mosque. The solution offered to the target partners is the need to hold a training outlining the work to achieve organizational goals and training in the organization of the mosque's youth organization. By conducting training activities, the organizational structure of mosque teenagers can be structured as a basis for determining the right people to fill the positions listed on the organizational chart. Organizations that are managed by the right people will produce activities that are able to meet the expectations of mosque worshipers. The training was able to increase the knowledge and skills of participants to develop the organizational structure of mosque youth for the prosperity of the mosque. Improving the skills of the trainees includes skills about describing indicators of organizational goals, types of activities, grouping of activities, describing interactions in the organization and job descriptions and specifications. In addition, the trainees experienced an increase in knowledge related to the concept of the role of management in achieving organizational goals, management functions specifically organizing, organizational structure, the right man in the right place, and the rights and obligations of management and members of the organization.
\end{abstract}

Keywords: training; job description; structure; organizational goals.

\begin{abstract}
ABSTRAK
Organisasi keagamaan seperti organisasi remaja masjid memiliki peran yang strategis terhadap kemakmuran masjid. Masjid yang makmur ditandai dengan semaraknya kegiatan ibadah para jamaahnya. Di Masjid Al Barokah, Kecamatan Cobodas, Kota Tangerang Banten organisasi remaja masjidnya kurang berjalan dengan teratur dan tearah. Berdasarkan observasi dan wawancara dengan pengurus Dewan Kemakmuran Masjid, akar permasalahannya adalah kurangnya pengetahuan untuk menyusun struktur organisasi remaja masjid yang efektif dan efisien. Solusi yang ditawarkan kepada mitra sasaran adalah perlu diadakannya pelatihan menguraikan pekerjaan untuk mencapai tujuan organisasi dan pelatihan penyusunan struktur organisasi remaja masjid. Dengan dilakukan kegiatan pelatihan maka dapat tersusun struktur organisasi remaja masjid sebagai dasar menentukan orang-orang yang tepat untuk mengisi jabatan yang tercantum pada bagan organisasi. Organisasi yang dikelola orang yang tepat akan menghasilkan kegiatan yang mampu memenuhi harapan jamaah masjid. Pelatihan mampu meningkatkan pengetahuan dan ketrampilan peserta untuk menyusun struktur organisasi remaja masjid untuk kemakmuran masjid. Peningkatan ketrampilan peserta pelatihan meliputi ketrampilan tentang menguraikan indikator tujuan organisasi, jenis kegiatan, pengelompokkan kegiatan, penggambaran interaksi dalam organisasi serta deskripsi dan spesifikasi jabatan. Selain itu peserta pelatihan mengalami peningkatan pengetahuan terkait dengan konsep tentang peran manajemen dalam mencapai tujuan organisasi, fungsi manajemen khususnya pengorganisasian, struktur organisasi, the right man in the right place, serta hak dan kewajiban pengurus dan anggota organisasi.
\end{abstract}

Kata kunci: pelatihan, uraian pekerjaan, struktur, tujuan organisasi.

\section{PENDAHULUAN}

Masjid sebagai organisasi keagamaan memiliki orientasi sosial, berperan penting dalam membentuk perkembangan pribadi maupun masyarakat disekitarnya. Keberadaannya di Indonesia 
membantu negara untuk memfasilitasi masyarakat muslim untuk melaksanakan nilai-nilai Pancasila. Masjid memiliki fungsi utama sebagai tempat beribadah sebagai perwujudan pelaksanaan sila pertama yaitu: "Ketuhanan Yang Maha Esa". Namun keberadaan masjid juga dapat berfungsi untuk memfasilitasi anggota masyarakat melaksanakan nilai-nilai kemanusiaan, persatuan, musyawarah maupun keadilan soasial yang tercantum dalam keempat sila lainnya dalam Pancasila.

Kegiatan yang dilakukan di masjid diarahkan sebagai kegiatan ibadah dalam rangka pengabdian manusia kepada Allah. Kegiatan ini dapat diklasifikasikan menjadi dua, yaitu dalam hubungannya dengan Allah (hablum minallah) dan dalam hubungannya dengan manusia (hablum minannas). Kegiatan hablum minallah dapat berupa pelaksanaan sholat baik yang terkait sholat wajib maupun sunnah. Kegiatan hablum minannas terkait dengan hubungannya sesama manusia dalam bermasyarakat, seperti mengumpulkan, memanfaaatkan, membagi: zakat, infaq, shodaqoh maupun amal jariyah lainnya. Disamping itu juga terdapat kegiatan yang menunjang untuk dua kegiatan tersebut seperti pendidikan maupun pengajian.

Berdasarkan hasil observasi dan diskusi dengan pengurus Dewan Kemakmuran Masjid AlBarokah di Jalan Loka Pala Raya, Kelurahan Cibodas, Kecamatan Cibodas, Kota Tangerang, Banten, menunjukkan kegiatan masjid masih belum mampu memenuhi harapan untuk mensejahterakan jamaah masjid. Kegiatan lebih banyak ditangani oleh Dewan Kemakmuran Masjid yang memiliki kendala waktu dan pemikiran serta kurang berkembangnya aktivitas Remaja Masjid yang menjadi generasi penerus. Atas dasar kondisi tersebut dipandang penting untuk menggerakkan organsiasi Remaja Masjid berperan sebagai ujung tombak dalam merencanakan, mengorganisir, mengkoordinir, melaksanakan serta mengendalikan kegiatan-kegiatan masjid untuk membantu Dewan Kemakmuran Masjid dalam memaksimumkan kemakmuran masjid.

Berdasarkan analisis situasi tersebut, maka kegiatan: Pelatihan Penyusunan Struktur Organisasi Remaja untuk Memaksimumkan Kemakmuran Masjid Al-Barokah di Kecamatan Cibodas, Kota Tangerang, Banten dapat mengatasi kesulitan yang dihadapi Dewan Kemakmuran Masjid tersebut.

\section{TINJAUAN PUSTAKA}

Maju mundurnya suatu organisasi sangat ditentukan oleh manajemen atau tata kelolanya. Manajemen memiliki beberapa fungsi. Menurut Terry yang diterjemahkan oleh Winardi (1986: 163), manajemen memiliki fungsi: perencanaan, pengorganisasian, penggerakan dan pengendalian. Untuk mencapai tujuan organisasi maka tidak mungkin jika hanya satu atau beberapa fungsi saja yang dijalankan tetapi keempat fungsi tersebut perlu dilakukan secara efektif dan efisien. Hal ini tidak hanya berlaku pada organisasi yang berorientasi laba tetapi juga yang non laba, seperti misalnya organisasi masjid.

Masjid merupakan organisasi yang memiliki tujuan untuk mencapainya perlu dilakukan pengelolaan secara efektif dan efisien melalui pelaksanaan fungsi-fungsi manajemen termasuk pengorganisasian. Pengorganisasian merupakan proses penentuan, pengelompokkan dan pengaturan bermacam-macam aktivitas yang diperlukan untuk mencapai tujuan, menempatkan orang-orang pada setiap aktivitas, menetapkan wewenang yang secara relatif didelegasikan kepada setiap individu yang akan melakukan aktivitas-aktivitas yang diperlukan tersebut (Hasibuan, 1989: 221).

Kegiatan pengorganisasian dirumuskan dalam bentuk penyusunan struktur organisasi. Organisasi merupakan entitas sosial yang sengaja didirikan untuk jangka waktu yang relatif lama, beranggotakan dua orang atau lebih yang bekerja bersama-sama dan terkoordinasi, memiliki pola 
kerja tertentu yang terstruktur, serta didirikan untuk mencapai tujuan bersama atau satu set tujuan yang telah ditentukan sebelumnya (Robbins, 2000). Struktur organisasi pada hakikatnya merupakan cara untuk menata unsur-unsur dalam organisasi dengan sebaik-baiknya, demi mencapai berbagai tujuan yang telah ditetapkan (Kusdi, 2009:176).

Tidak berjalannya kaderisasi berorganiasi bagi remaja masjid pada kahlayak sasaran tersebut, dapat di atasi dengan diadakan program pengabdian masyarakat yang dilakukan oleh Direktorat Penelitian dan Pengabdian Masyarakat Universitas Tarumanagara. Program yang ditawarkan kepada khalayak sasaran yaitu pengurus Dewan Kemakmuran Masjid Al-Barokah dan remaja masjidnya dalam bentuk: Pelatihan Penyusunan Struktur Organisasi Remaja Masjid untuk Memaksimumkan Kemakmuran Masjid Al-Barokah di Kecamatan Cibodas, Kota Tangerang, Banten.

\section{Pelatihan Uraian Pekerjaan}

Langkah awal sebelum menyusun struktur organisasi adalah membuat uraian berbagai pekerjaan yang perlu dilakukan untuk mencapai visi, misi, dan tujuan organisasi. Visi mencerminkan apa yang dicita-citakan dari didirikannya organisasi. Misi menunjukkan kegiatan utama yang dilakukan organisasi untuk mencapai visinya. Sedangkan tujuan organisasi menggambarkan halhal yang ingin dicapai dalam satu periode biasanya dalam satu tahun melalui pelaksanaan berbagai kegiatan.

Dengan demikian tujuan merupakan turunan dari visi dan misi organisasi. Untuk merealisasikan suatu tujuan memerlukan pelaksanaan berbagai aktivitas. Semua kegiatan yang diperlukan perlu ditulis, selanjutnya dilakukan pengelompokkan kegiatan atau departementalisasi. Berdasarkan pengelompokkan kegiatan maka selanjutnya dapat dijadikan dasar disusunnya struktur organisasi.

\section{Pelatihan Penyusunan Struktur Organisasi}

Setelah mitra atau peserta dapat menguraikan berbagai kegiatan untuk mencapai tujuan organisasi, maka dilanjutkan dengan pelatihan penyusunan struktur organisasi. Materi pelatihan yang disampaikan terkait dengan merancang struktur organisasi remaja masjid yang transparan dan akuntabel. Transparan dalam arti bahwa struktur organisasi yang diwujudkan dalam bentuk bagan organisasi mampu mengkondisikan sistem organisasi yang terbuka dimana anggota organisasi secara tidak langsung maupun langsung dapat mengetahui keputusan dan hasil dari keputusan yang diambil oleh pengelola/ pengurus remaja masjid. Akuntabel dalam arti bahwa bagan oganisasi mengakomodir fungsi pengawasan terhadap pengelola/pengurus remaja masjid, sehingga laporan yang dihasilkan dapat dipertanggungjawabkan kepada anggota organisasi. Bagan organisasi remaja masjid dapat dilihat pada Gambar 1.

Tidak mudah untuk melakukan standarisasi struktur organisasi remaja masjid, karena setiap masjid walaupun fungsi utamanya sama yaitu sebagai tempat ibadah khusus (madhoh), tetapi dimungkinkan adanya berbagai variasi kegiatan. Namun demikian bentuk struktur organisasi pada gambar berikut ini dapat menjadi sumber inspirasi untuk mengatasi kelemahan struktur oganisasi yang selama ini ada dan banyak dipakai pada berbagai masjid. 


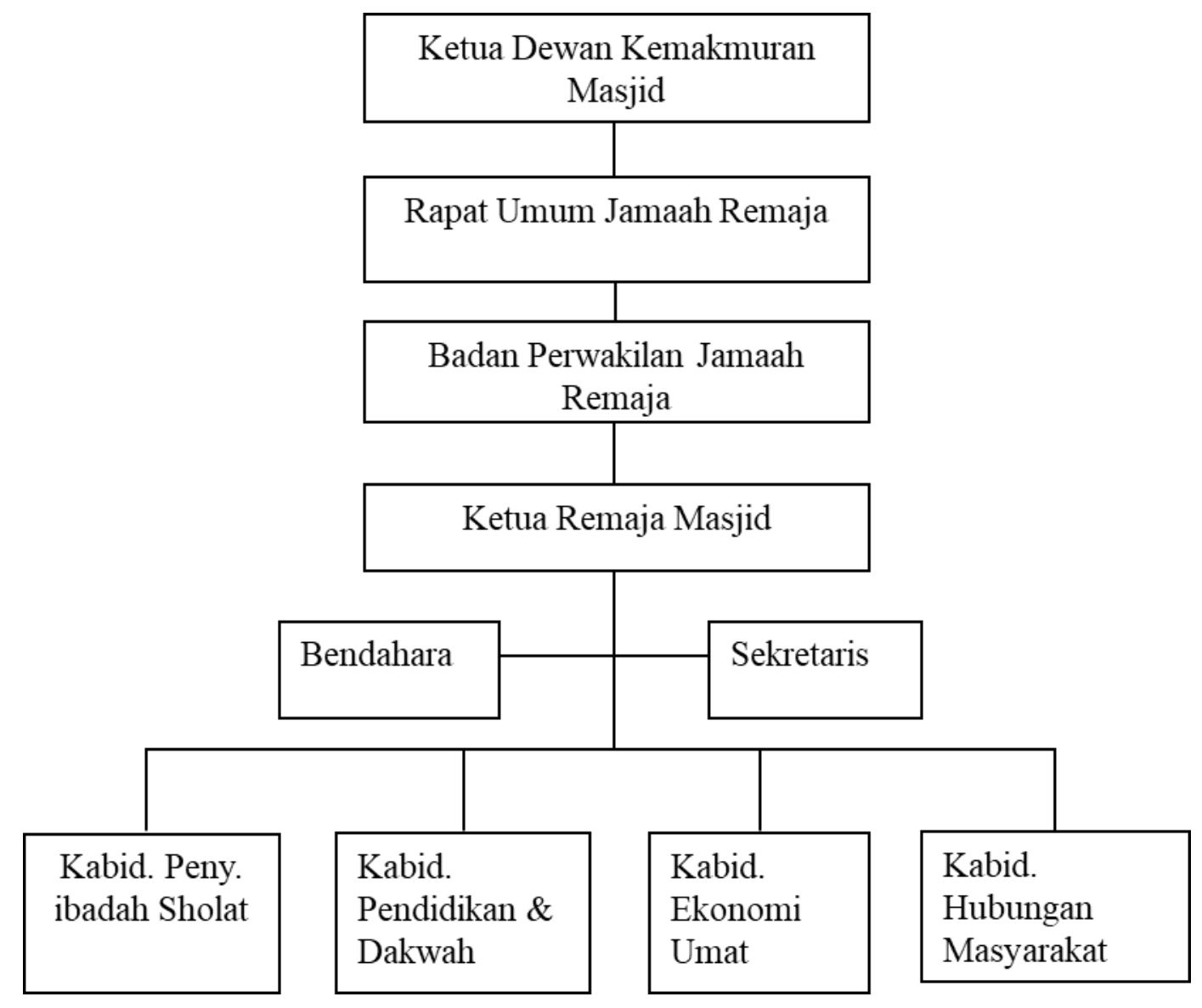

Gambar 1. Bagan Organisasi Remaja Masjid

Dewan Kemakmuran Masjid, memiliki tugas untuk:

1. Bertanggung jawab atas harta dan kegiatan yang dilakukan oleh masjid kepada jamaah masjid.

2. Berkewajiban melaksanakan kegiatan untuk memakmurkan masjid.

3. Mengadakan pembinaan terhadap kegiatan yang dilakukan oleh organisasi remaja masjid.

Rapat Umum Jamaah, memiliki tugas untuk:

1. Mengesahkan anggaran dasar dan rumah tangga oganisasi.

2. Mengangkat Badan Perwakilan Jamaah dan Ketua RemajaMasjid.

3. Menilai laporan pertanggungjawaban Pengurus Remaja Masjid.

4. Mengawasi Badan Perwakilan Jamaah Remaja Masjid.

5. Memberhentikan Badan Perwakilan Jamaah dan Ketua Remaja Masjid.

Badan Perwakilan Jamaah, memiliki tugas mewakili jamaah untuk:

1. Mengawasi Ketua Remaja Masjid.

2. Mensyahkan program kerja Ketua RemajaMasjid.

3. Memberikan pertimbangan jika diminta terhadap keputusan Ketua Remaja Masjid

4. Menyelenggarakan Rapat Umum Jamaah Remaja Masjid.

5. Mengusulkan kepada Rapat Umum Jamaah Remaja Masjid untuk melakukan pergantian pengurus sebelum waktunya jika dipandang Ketua Remaja Masjid tidak mampu melakukan tugasnya. 
Ketua Remaja Masjid, memiliki tugas:

1. Merumuskan tujuan dan sasaran organisasi.

2. Menyusun program kerja untuk mencapai tujuan dan sasaran organisasi.

3. Mengangkat para pembantunya yaitu: sekretaris, bendahara dan para kepala bidang/seksi.

4. Memberhentikan para pemabantunya yang dinilai tidak mampu melaksankan tugastugasnya.

5. Melaporkan pelaksanaan program kerja kepada Badan Perwakilan Jamaah Remaja Masjid.

6. Mempertanggungjawaban tugasnya dalam Rapat Umum Jamaah Remaja masjid.

Sekretaris, memiliki tugas yaitu: membantu Ketua Remaja Masjid dalam hal:

1. Penyusunan surat menyurat.

2. Mempersiapkan pelaksanaan rapat dan menyusun notulen rapat.

3. Melakukan arsip terhadap surat masuk dan keluar serta meyelenggarakan kegiatan kesekretariatan lainnya.

4. Melaporkan tugas-tugas kesekretariatan dan mempertanggungjawabkannya kepada Ketua Remaja Masjid.

Bendahara bertugas membantu Ketua Remaja Masjid untuk :

1. Menyelenggarakan pembukuan keungan masjid.

2. Mencari sumber pendanaan masjid.

3. Mengendalikan pengeluaran dana masjid.

4. Menjaga keamanan dana masjid.

5. Melaporkan dan mempertanggungjawabkan keuangan masjid kepada Ketua Remaja Masjid.

Kepala Bidang Penyelenggaraan Ibadah Sholat, bertugas membantu Ketua Remaja Masjid untuk:

1. Memfasilitasi penyelenggaraan sholat terutama sholat lima waktu dan sholat Jum'at secara berjamaah.

2. Mengatur jadwal yang menjadi muadzin, imam, khatib sehingga pelaksanaan ibadah sholat berjalan tepat waktu.

Kepala Bidang Pendidikan dan Dakwah, bertugas membantu Ketua Remaja Masjid untuk:

1. Menyelenggrakan kegiatan pendidikan dan pelatihan terutama untuk meningkatkan pengetahuan dan ketrampilan para jamaah masjid.

2. Menyelenggarakan kegiatan dakwah terutama dalam menyambut hari besar Islam maupun bulan Romadhon.

3. Melaporkan kegitannya dan bertanggungjawab kepada Ketua Pengurus Masjid.

Kepala Bidang Ekonomi Umat, bertugas membantu Ketua Remaja Masjid untuk:

1. Mendata kondisi ekonomi para jamaah, terutama yang menjadi pengangguran.

2. Mencarikan jalan keluar terhadap jamaah yang kondisi ekonominya lemah.

3. Menjajaki kemungkinan untuk bekerjasama dengan fihak lain untuk mengadakan atau mengikuti pelatihan kewirausahaan.

4. Menjalin kerjasama untuk memperoleh sumber pendanaan guna mendukung program kewirausahaan.

5. Membangun jaringan ekonomi antar masjid untuk membangun kekuatan yang dapat diperhitungkan oleh para pelaku ekonomi.

6. Membuat program kerja yang dapat meningkatkan ekonomi umat. 
7. Menyampaikan laporan dan bertanggungjawab atas tugasnya kepada Ketua Pengurus Masjid.

Kepala Bagian Hubungan Masyarakat, bertugas membantu Ketua Remaja Masjid untuk:

1. Menjalin komunikasi dengan jamaah masjid dan pengurus masjid lainnya, agar dalam melaksanakan program kerja organisasi masjid dapat berjalan dengan lancar.

2. Menjalin hubungan yang harmonis dengan para ustadz, kyai dan lainnya sehingga dapat mendukung pendidikan dan dakwah yang menjadi program kerja organisasi masjid.

3. Menjalin hubungan yang baik dengan para donatur dan sponsor.

4. Menjaga hubungan baik dengan pemerintah, aparat keamanan, dan masyarakat luas.

5. Melaporkan tugas-tugasnya dan bertanggungjawab kepada Ketua Pengurus Masjid.

Berdasarkan bagan organisasi tersebut, nampak adanya fungsi pengendalian yang dilakukan oleh Badan Perwakilan Jamaah Remaja Masjid. Sebenarnya nama-nama dalam bagan organisasi tersebut dapat disesuaikan dengan besar kecilnya organisasi, tujuan dan kompleksitas kegiatannya. Bagan tersebut disajikan dengan menekankan adanya sistem oraganisasi yang menghasilkan transparasi dan akuntabilitas pengelolaan.

\section{METODE PELAKSANAAN PKM}

Kegiatan pengabdian masyarakat dilakukan mulai Pebruari 2019 sampai dengan Juli 2019. Populasi kegiatan adalah mitra atau khalayak sasaran yaitu para jamaah khususnya pengurus dan calon pengurus DKM dan pengurus dan calon pengurus Remaja Masjid Albarokah, Jl Lokapala Raya, RW 08, Kelurahan Cibodas, Kecamatan Cibodas, Kota Tangerang, Banten. Sedangkan yang menjadi sampel kegiatan setidaknya sebanyak 30 orang. Metode penyampaian materi dilakukan dengan ceramah dan tanya jawab. Sebelum pelaksanaan pelatihan, dilakukan pretest untuk mengetahui pengetahuan peserta tentang penyusunan struktur organisasi remaja masjid. Setelah selesai pelatihan dilakukan postest dengan menggunakan pertanyaan yang sama untuk mengetahui ada tidaknya pengaruh pelatihan terhadap pengetahuan peserta tentang pengetahuan dan ketrampilannya. Alat analisis yang digunakan adalah uji beda yaitu wilcoxon match pairs test.

\section{Tahap Kegiatan PKM}

Kegiatan secara garis besar terbagi dalam 5 tahap dengan rincian kegiatan tertera dalam Tabel 1.

Tabel 1. Jadwal Pelaksanaan Kegiatan

\begin{tabular}{|l|l|l|}
\hline No. & Waktu & Kegiatan \\
\hline 1. & Awal Pebruari 2019 & Diskusi dengan perwakilan mitra/ khalayak sasaran \\
2. & Pertengahan Pebruari 2019 & Menyusun dan menyampaikan proposal kegiatan \\
3. & Maret-April 2018 & Koordinasi dengan mitra/khalayak sasaran tentang pelaksanaan kegiatan \\
4. & Mei-Juli 2019 & Pelaksanaan kegiatan dan pengumpulan data \\
5. & Juli 2019 & Laporan pelaksanaan kegiatan \\
\hline
\end{tabular}

\section{HASIL PELAKSANAAN KEGIATAN DAN PEMBAHASAN \\ 1. Hasil Pelaksanaan Kegiatan}

\section{a. Analisis Pelaksanaan Pelatihan}

Pelatihan dapat terlaksana, berkat kerjasama Tim PKM Universitas Tarumanagara dengan Pengurus BKM Al Barokah Alamat: Jalan Loka Pala Raya, RW 08, Kelurahan Cibodas, Kecamatan Cibodas, Kota Tangerang, Banten 15138 yang diketua oleh A. Dadang S. Dengan kerjasama tersebut, maka mempermudah TIM PKM universitas Tarumanagara dalam melaksanakan pelatihan. Pengurus DKM mempersiapkan peserta, tempat, fasilitas pelatihan 
sedangkan TIM PKM Universitas Tarumanagara menyampaikan materi pelatihan beserta kelengkapannya. Dari sisi organiasi pelaksanaan pelatihan berjalan tanpa ada hambatan.

Pelaksanaan pelatihan dilakukan pada Minggu, 7 Juli 2019 di Masjid Al-Barokah Jalan Loka Pala Raya, RW 08, Kelurahan Cibodas, Kecamatan Cibodas, Kota Tangerang, Banten. Pelatihan dimulai dengan peserta mendata peserta, selanjutnya peserta diberikan pretest untuk mengetahui pengetahuan dan ketrampilannya tentang penyusunan struktur organisasi remaja untuk memakmurkan masjid. Setelah itu TIM PKM Universitas Tarumanagara memberikan ceramah dan tanya jawab tentang materi pelatihan. Kegiatan pelatihan diakhiri dengan postest untuk mengetahui dampak pelatihan terhadap pengetahuan dan ketrampilan peserta. Ketika pelatihan sedang berlangsung juga dilakukan pendokumentasian kegiatan. Berdasarkan evaluasi pelaksanaan kegiatan pelatihan, maka kegiatan pelatihan dinilai dapat berlangsung dengan lancar, walaupun peserta pelatihan juga diminta untuk mengisi angket pretest dan postest sedangkan para peserta memiliki latar belakang pendidikan dan usia yang sangat beragam.

\section{b. Analisis Statistik Diskriptif}

Statistik deskriptif menyajikan gambaran tentang demografi dan pengetahuan responden terhadap peran dan pendirian koperasi syariah. Tabel 2 menyajikan gambaran responden meliputi umur, gender dan status perkawinan. Rata rata umur responden 2,37 yang berarti berumur dalam rentang 20-40 tahun tahun, dengan gender semuanya pria dan rata-rata status perkawinannya 1,40 yang berarti lebih dekat 1(kawin) dari pada 2 (tidak kawin).

Tabel 2. Statistik Deskriptif Demografi Responden

\begin{tabular}{lr|r|r|r|r} 
& N & Minimum & \multicolumn{1}{c}{ Maximum } & \multicolumn{1}{c}{ Mean } & \multicolumn{1}{c}{ Std. Deviation } \\
\hline Umur & 30 & 1,00 & 4,00 & 2,3667 & 1,09807 \\
\hline Gender & 30 & 1,00 & 1,00 & 1,00 &, 00000 \\
\hline Status & 30 & 1,00 & 2,00 & 1,40 &, 49827 \\
\hline Valid N (listwise) & 30 & & & & \\
\hline Keterangan & & & &
\end{tabular}

Keterangan:

Umur : 1 (15 s.d 20 tahun), 2 (di atas 20 s.d 25 tahun), 3 (di atas 25s.d 40 tahun), 4 (di atas 40 tahun).

Gender: 1 (pria), 2 (wanita).

Status : 1 (kawin), 2 (tidak kawin).

Dari Tabel 3 variabel pengetahuan tentang penyusunan struktur organisasi menunjukkan nilai negativ ranks untuk $\mathrm{N}$ menunjukkan 0 , dengan demikian nilai postest yang lebih kecil dari nilai pretest sama dengan 0 maka semua nilai rata-rata postest dari 30 responden lebih tinggi dari nilai rata-rata pretestnya. Selanjutnya nilai positiv ranks untuk N menunjukkan 30 , hal ini berarti semua nilai rata-rata dari 30 responden untuk postest lebih besar dari nilai pretest. Nilai ties pada $\mathrm{N}$ sebesar 0 , dengan demikian maka tidak ada nilai responden yang postest sama dengan pretestnya.

Untuk variabel ketrampilan dalam menyusun struktur organisasi menunjukkan nilai negativ ranks untuk $\mathrm{N}$ menunjukkan 0 , dengan demikian nilai postest yang lebih kecil dari nilai pretest sama dengan 0 maka semua nilai rata-rata postest dari 30 responden lebih tinggi dari nilai rata-rata pretestnya. Selanjutnya nilai positiv ranks untuk N menunjukkan 30, hal ini berarti semua nilai rata-rata dari 30 responden untuk postest lebih besar dari nilai pretest. 
Nilai ties pada $\mathrm{N}$ sebesar 0 , dengan demikian maka tidak ada nilai responden yang postest sama dengan pretestnya.

Tabel 3. Wilcoxon Signed Ranks Test

\begin{tabular}{|c|c|c|c|c|}
\hline & & $\mathrm{N}$ & Mean Rank & Sum of Ranks \\
\hline \multirow{4}{*}{$\begin{array}{l}\text { Pengetahuan_Postest - } \\
\text { Pengetahuan_Pretest }\end{array}$} & Negative Ranks & $0^{\mathrm{a}}$ & ,00 & ,00 \\
\hline & Positive Ranks & $30^{\mathrm{b}}$ & 15,50 & 465,00 \\
\hline & Ties & $0^{\mathrm{c}}$ & & \\
\hline & Total & 30 & & \\
\hline \multirow{4}{*}{$\begin{array}{l}\text { Ketrampilan_Postest - } \\
\text { Ketrampilan_Pretest }\end{array}$} & Negative Ranks & $0^{\mathrm{d}}$ &, 00 & ,00 \\
\hline & Positive Ranks & $30^{\mathrm{e}}$ & 15,50 & 465,00 \\
\hline & Ties & $0^{f}$ & & \\
\hline & Total & 30 & & \\
\hline
\end{tabular}
a. Pengetahuan_Postest $<$ Pengetahuan_Pretest
b. Pengetahuan_Postest > Pengetahuan_Pretest
c. Pengetahuan_Postest $=$ Pengetahuan_Pretest
d. Ketrampilan_Postest $<$ Ketrampilan_Pretest
e. Ketrampilan_Postest > Ketrampilan_Pretest
f. Ketrampilan_Postest $=$ Ketrampilan_Pretest

\section{c. Hasil Uji Wilcoxon Match Pairs Test}

Untuk mengetahui apakah ada perbedaan pengetahuan responden terhadap pengetahuan dan ketrampilan untuk menyusun struktur organisasi remaja masjid sebelum dan setelah pelatihan maka dilakukan uji Wilcoxon Match Pairs Test. Uji ini mensyaratkan data indikator dari variabel memiliki skala ordinal, dan data yang diperoleh memenuhi persyaratan tersebut. Tabel 4 menunjukkan hasil uji beda pretest dan postest untuk variabel penelitian.

\section{Tabel 4. Test Statistics ${ }^{a}$}

\begin{tabular}{lr|rr} 
& $\begin{array}{c}\text { Pengetahuan_Postest - } \\
\text { Pengetahuan_Pretest }\end{array}$ & \multicolumn{2}{c}{$\begin{array}{c}\text { Ketrampilan_Postest - } \\
\text { Ketrampilan_Pretest }\end{array}$} \\
\hline Z & $-4,814^{\mathrm{b}}$ & $-4,805^{\mathrm{b}}$ \\
\hline Asymp. Sig. (2-tailed) &, 000 &, 000 \\
\hline $\begin{array}{l}\text { a. Wilcoxon Signed Ranks Test } \\
\text { b. Based on negative ranks. }\end{array}$ & & & \\
\hline
\end{tabular}

Berdasarkan Tabel 4, hasil test statistics untuk pretest-postest pengetahuan penyusunan struktur organisasi remaja masjid menunjukkan asymp. sig. (2-tailed) 0,000 lebih kecil dari 0,05 , hal ini berarti terdapat perbedaan yang signifikan pengetahuan responden tentang pengetahuan penyusunan struktur organisasi sebelum dan setelah pelatihan. Demikian pula hasil test statistics untuk pretest-postest ketrampilan penyusunan struktur organisasi menunjukkan asymp. sig. (2-tailed) 0,000 lebih kecil dari 0,05 hal ini berarti terdapat perbedaan yang signifikan pengetahuan responden tentang ketrampilan untuk menyusun struktur organisasi remaja masjid sebelum dan setelah pelatihan. 


\section{Pembahasan}

Berdasarkan hasil uji statistik tersebut menunjukkan terdapat perbedaan antara hasil postest dengan hasil pretest untuk pengetahuan responden dalam penyusunan struktur organisasi remaja masjid. Dengan demikian penting ketika memberikan pelatihan yang efektif untuk memberikan pemahaman tentang pengetahuan dalam menyusun struktur organisasi meliputi: peran manajemen dalam mencapai tujuan organisasi, fungsi manajemen khususnya pengorganisasian, struktur organisasi, the right man in the right place, serta hak dan kewajiban pengurus dan anggota organisasi.

Demikian pula terdapat perbedaan yang signifikan antara hasil postest dengan pretest untuk ketrampilan responden dalam menyusun struktur organisasi remaja masjid. Hal demikian memberikan petunjuk bahwa kegiatan pelatihan yang efektif dapat meningkatkan ketrampilan peserta pelatihan khususnya berkaitan dengan: indikator tujuan organisasi, jenis kegiatan, pengelompokkan kegiatan, pengambaran interaksi dalam organisasi serta deskripsi dan spesifikasi jabatan.

\section{KESIMPULAN DAN SARAN}

Berdasarkan uraian tersebut, maka dapat ditarik beberapa kesimpulan sebagai berikut:

a. Kegiatan pelatihan penyusunan struktur organisasi masjid dalam pelaksanaanya dapat berjalan dengan lancar, hal ini berkat adanya kerjasama yang baik antara Tim PKM Universitas Tarumanagara dengan pengurus BKM Masjid Al-Barokah, Cibodas, Kota Tangerang, Banten.

b. Pelatihan yang dilakukan dapat meningkatkan pengetahuan peserta tentang penyusunan struktur organisasi remaja masjid. Peserta pelatihan mengalami peningkatan pengetahuan terkait dengan konsep tentang peran manajemen dalam mencapai tujuan organisasi, fungsi manajemen khususnya pengorganisasian, struktur organisasi, the right man in the right place, serta hak dan kewajiban pengurus dan anggota organisasi.

c. Pelatihan yang dilakukan dapat meningkatkan ketrampilan peserta tentang. penyusunan struktur organisasi remaja masjid. Peningkatan ketrampilan peserta pelatihan meliputi ketrampilan tentang menguraikan indikator tujuan organisasi, jenis kegiatan, pengelompokkan kegiatan, pengambaran interaksi dalam organisasi serta deskripsi dan spesifikasi jabatan.

Berdasarkan kesimpulan tersebut, maka dapat disarankan sebagai berikut:

a. Bagi pengurus remaja masjid perlu melakukan pelatihan khususnya tentang penyusunan struktur organisasi kepada calon pengurus remaja masjid. Hal ini dilakukan agar kegiatan yang dilakukan oleh mengarah pada pencapaian visi, misi serta tujuan dan sasaran organisasi. Tidak menutup kemungkinan untuk menyelenggarakan kegiatan pelatihan lainnya, karena keberhasilan organisasi banyak dipengaruhi faktor lainnya seperti kepemimpinan, penyusunan program kerja, penyusunan anggaran, penyusunan laporan keuangan dan sebagainya.

b. Bagi perguruan tinggi, dapat terus berkontribusi dengan melakukan pelatihan penyusunan struktur organisasi maupun pelatihan tentang tata kelola organisasi lainnya kepada para pengurus maupun calon pengurus organisasi keagamaan maupun kemasyarakatan yang lain agar dapat mencapai tujuannya secara efektif dan efisien

\section{Ucapan Terima Kasih}

Kegiatan PKM ini dapat terlaksana berkat kerjasama antara Universitas Tarumanagara dengan kompnen masyarakat. Oleh karena itu, izinkan kami mengucapkan banyak terima kasih kepada:

a. Universitas Tarumanagara melalui Direktur DPPM dan para stafnya yang telah memfasilitasi dan mendanai kegiatan PKM. 
b. DKM Masjid Al-Barokah Jalan Loka Pala Raya, RW 08, Kelurahan Cibodas, Kecamatan Cibodas, Kota Tangerang, Banten 15138 melalui Ketua dan pengurus lainnya yang mengundang peserta, menyediakan tempat serta akomodasi lainnya sehingga kegiatan PKM dapat berjalan dengan lancar.

Tanpa kerjasama yang baik dengan mereka maka kami tidak dapat melaksanakan kegiatan PKM dengan lancar. Semoga pelatihan yang telah diikuti dapat membawa manfaat bagi kemakmuran masjid tersebut.

\section{REFERENSI}

Hasibuan, M. S. P. 1989. Manajemen Dasar: Pengertian dan Masalah. Jakarta: Gunung Agung. Kusdi. 2009. Teori Organisasi dan Administrasi. Jakarta: Penerbit Salemba Humanika.

Robbins, S. dan Coulter, M. 2007. Manajemen. Edisi Kedelapan, Jakarta: PT Indeks.

Robbins, S. P. 2000. Organizational Behavior: Concepts, Controversies and Applications. Eight Edition. Englewood Cliffs, N.J.: Prentice Hall Inc.

Terry, G.R. alih bahasa Winardi .1986. Asas-asas Manajemen. Bandung: Alumni. 